537.

\title{
放射線治療システムの構築 Constraction of Radiation Therapy System
}

\section{滋賀医科大学附属病院 放射楾部}

\section{○吉村雅宽 木田哲生 本多恵理子 檑本惠次 近薜康雄}

当施設においてリニアックのリプレイスにあたり、放射線治療の最適化を目指しシステム構築を行った ので報告する。

創設当時の放射線治療システムによる治療計画のブロック図をＦｉｇ．1に示す。

治㙩計画の方針は、診断用フイルム画像より Target を設定し、X線シミュレーターで位置決めを行い、モ ノブロックにより不整形照射野の設定を行っていた。そして照射野枠にカテーテルを張り付け、診断用C $\mathrm{T}$ で確認し最終的にはシミュレーションX楾写真とリニアックグラフィーを照合して確認を行っていた。

F i g . 2 は現在の放射線治療システムのブロック図を示す。C T とX楾シミュレーターは唚台を 90 度 回転させることで共有でき、治療体位でのC T撮影が可能である。また、C TデータはYM S 製R Tマーカー に転送し、Target 、Critical OrganのRO I を設定することで Target に限局したマルチリーフコリメー ター（以下MLC）：26対）の照射野が決定される。その結果をプリントアウトし、画像をMLC Shaper に入力してML CWorkstationに転送することで、MLCを制御する。

患者の治療データは患者自動照合装置（RMS2000）で管理され、治療室内にも同様なモニターを配して いる。モニターには、治療パラメーターを表示しており、それぞれのインターロックを解除（赤から白字） することで照射が可能となり、照射結果はプリントアウトされる。

また、治療患者の画像デ一タは、Medifileで管理しており、MODで保管している。

創設当時のシステムの問題点は

1. 治療体位とは違う診断用画像でのTarget Volumeの設定には不正確さがあり照射野設定後力テー・ルル 等をはり再度診断用CTで確認を行う必要があった。

2. 不整形照射野はモノブロックを使用するため Target Volumeの形はブロックの形状に依存していた。

3. 患者毎の治療データおよび照射記録は治療力ルテに依存していた為,人的ミスの生じる可能性があった。 上記の経験からFig．2に示すシステムを構築し、その問題点も改善した。

(まとめ)

1. C Tシミュレーター、R Tマーカーを利用することでより正確かつ多種類の Treatment Field の設定 ができるようになった。

2 ．上記で設定された Treatment Fleld に対しML C を利用することで Target Volumeに限局した Field が設定できるようになった。

3．患者自動照合照合装置により、日々の照射に対し正確性かつ効率がよくなった。

4. 創設時に比べ、コンピューター技術の発達によりソフト、ハードの面でより充実がなされ、より正確な Targt に対する最適化をおこなえるシステムの構築ができた。

\section{創設当時の放射線治㞠 S Y S T EM}

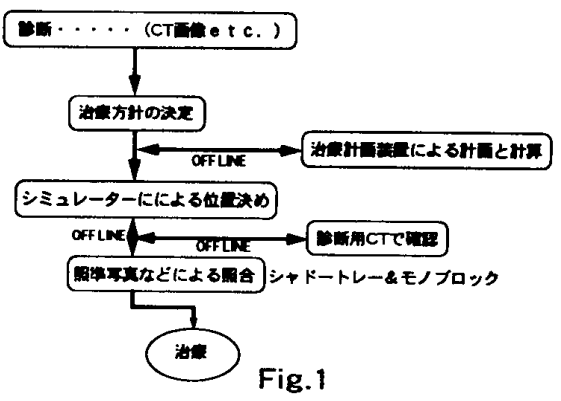

\section{現在の放射線治寮 S Y S T E M}

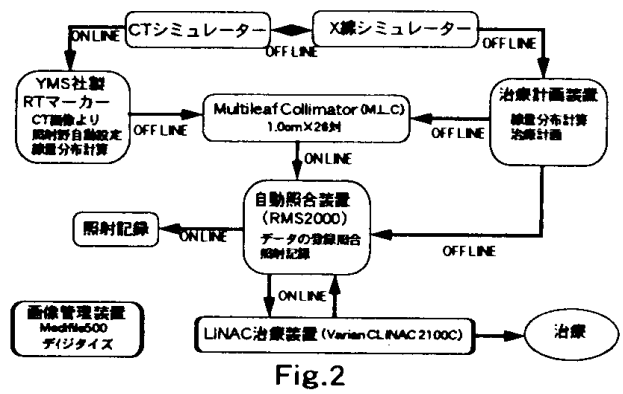

